\title{
Women in Development: A Critique of Neo-Classical Economic Theory as One of the Causes for Gender Inequality
}

\author{
Reham El Morally \\ Department of International Development, School of Agriculture Policy and Development, University of Reading, Reading, UK \\ Email: r.elmorally@pgr.reading.ac.uk
}

How to cite this paper: El Morally, R. (2020). Women in Development: A Critique of Neo-Classical Economic Theory as One of the Causes for Gender Inequality. Open Journal of Political Science, 10, 1-14. https://doi.org/10.4236/ojps.2020.101001

Received: October 7, 2019

Accepted: December 3, 2019

Published: December 6, 2019

Copyright $\odot 2020$ by author(s) and Scientific Research Publishing Inc. This work is licensed under the Creative Commons Attribution International License (CC BY 4.0).

http://creativecommons.org/licenses/by/4.0/

\begin{abstract}
This research reviews and critiques neoliberalism and neoclassical economics for them being one of the main causes for the subordination and oppression of women. This research does not claim that neoliberalism is the axis of evil; however it discusses how alternative economic and political theories can be more useful and efficient for women and gender development. The research question is mainly concerned with how far do neoclassical economic theories perpetuate and intensify power struggle between genders? The research argues for neoclassical economic theory being a main driving force in the subordination and oppression of women, especially in global South countries that have been subjugated to structural adjustment. In order to do so, this research utilizes an intersectional feminist framework of analysis to methodologically deconstruct neoclassical economic theory and critically investigate their gendered effects on beneficiary countries. Moreover, the political conceptual framework of "inside-outside", pioneered by Robert Cox, is the analytical tool used throughout this research. The research will, therefore, first clarify the difference between gender and sex, and clarify what I mean when I say "neoclassical economic theory". Followed by a criticism of how neoclassical economics is a theory of discrimination. An argument for the non-existence of a separation between the global level and the social level when analyzing gender relations will be the primary objective of this study. Lastly, the research discusses how structural adjustment programs affect women, specifically women living in poverty and armed conflict.
\end{abstract}

\section{Keywords}

Gender Dynamics, Neo-Classical Economics, Discrimination, Global Economy, Structural Adjustment Programs, Global South 


\section{Introduction}

"Criticism may not be agreeable, but it is necessary. It fulfills the same function as pain in the human body. It calls attention to an unhealthy state of things" Winston Churchill

Currently, there is an ever-growing awareness regarding the significance of women's economic and political participation. Women play a key role in the development of national economy and improving the living standards of individual households. ${ }^{2}$ However research about the significance of women to development of the global South seems to be ignored rather than taken seriously. This, I believe, is due to the power relations in the global arena. The global hegemonic powers have the power to claim they are the producers of truthful knowledge while those who possess less power are ignored, patronized, and paternalized. In a Ted Talk Ernesto Sirolli said: "We Western people are imperialist, colonialist missionaries, and there are only two ways we deal with people: We either patronize them, or we are paternalistic. The two words come from the Latin root 'Pater,' which means, 'Father.' But they mean two different things. Paternalistic, I treat anybody from a different culture as if they were my children. 'I love you so much.' Patronizing, I treat everybody from another culture as if they were my servants". ${ }^{3}$ His talk illustrates the neoliberal approach to economic empowerment around the world, carried out mainly by the Bretton Woods Institutions - the International Monetary Fund (IMF), World Trade Organization (WTO), and the World Bank, that were established after the Second World War and were aiming to help rebuild the shattered postwar economy (mainly that of Europe) and to promote international economic cooperation- ${ }^{4}$

This quote by Winston Churchill illustrates what my paper is talking about. In this paper I shall critique neoliberalism and neoclassical economics for them being one of the main causes for the subordination and oppression of women. I am not claiming that neoliberalism is the axis of evil; however I will discuss how alternative economic and political theories can be more useful and efficient for women. My question is mainly concerned with how far do neoclassical economic theories perpetuate and intensify power struggle between genders? I will argue for neoclassical economic theory being a main driving force in the subordination and oppression of women, especially in global South countries that have been ${ }^{1}$ Was a British politician who was the Prime Minister of the United Kingdom from 1940 to 1945 and again from 1951 to 1955 . He was widely regarded as one of the greatest wartime leaders of the 20th century; Churchill was also an officer in the British Army, a historian, a writer, and an artist. He won the Nobel Prize in literature, and was the first person to be made an honorary citizen of the United States.

${ }^{2}$ Sarah Bradshaw, Joshua Castellino, and Bineta Diop, "Women's Role in Economic Development: Overcoming the Constraints", in Challenges of Social Inclusion: Gender, Inequalities and Human Rights, (New York: Middlesex University Press, March 2012): 1-15.

${ }^{3}$ Ernesto Sirolli, "Want to help someone? Shut up and Listen", Ted.com/talks, November 2012, Web. https://www.ted.com/talks/ernesto_sirolli_want_to_help_someone_shut_up_and_listen/transcript?1 anguage $=$ en, (accessed May 1, 2015).

${ }^{4}$ Bretton Woods Projects, "What are the Bretton Woods Institutions", BrettonWoodsProject.org, August 23, 2005, Web. http://www.brettonwoodsproject.org/2005/08/art-320747/, (accessed May 1, 2015) 
subjugated to structural adjustment. In order to do so I will first clarify the difference between gender and sex, and clarify what I mean when I say "neoclassical economic theory".

On the first hand we have to understand what neoclassical economic theory is. The Business Dictionary defines neoclassical economics as "Present day dominant school of economic thought built on the foundation laid by the 18th century (classical) theories of Adam Smith (1723-1790) and David Ricardo (1772-1823), and refined by the 19th and 20th century theories of Alfred Marshall (1842-1924), Vilfredo Pareto (1848-1923), John Clark (1847-1938), and Irving Fisher (1867-1947). It is 'classical' in the sense that it based on the belief that competition leads to an efficient allocation of resources, and regulates economic activity that establishes equilibrium between demand and supply through the operation of market forces. It is 'neo' in the sense that it departs sharply from the classical viewpoint in its analytic approach that places great emphasis on mathematical techniques. In opposition to Keynesian economics, this school states that savings determine investment (not the other way round), and is concerned primarily with market equilibrium and growth at full employment instead of with the under-employment of resources". 5

Furthermore, in neo-classical economic theory, it is claimed without evidence that people are basically self-seeking, that they want above all the satisfaction of their material desires: what economists call "maximizing utility". The ultimate objective of mankind is economic growth, and that is maximized only through raw, and lightly regulated, competition. If the rewards of this system are spread unevenly, that is a necessary price. Others on the planet are to be regarded as customers, competitors or factors of production. Effects upon the planet itself are mere "externalities" to the model, with no calculation of the cost-at least for sufficiently. "Nowhere in this analysis appear factors such as human cooperation, love, trust, compassion or hatred, curiosity or beauty. Nowhere appears the concept of meaning. What cannot be measured is ignored. But the trouble is that once our basic needs for shelter and food have been met, these factors may be the most important of all" (Ross \& Kozloff, 2012). ${ }^{6}$ In other words the theory is based on thin air, because it assumes that the ultimate goal of people is material maximization with a minimization of cost, effort and time. It assumes the market can reach equilibrium without intervention from the state, and that an increase in prices will contribute to the pace of equilibrium. ${ }^{7}$

On the other hand we must differentiate between gender and sex. So gender refers to the array of socially constructed roles and relationships, personality traits, attitudes, behaviors, values, relative power and influence that society ascribes to the two sexes on a differential basis. Whereas biological sex is deter${ }^{5}$ The Business Dictionary, “Definition: Neo Classical Economics”, Businessdictionary.com, 2015, Web. http://www.businessdictionary.com/definition/neo-classical-economics.html, (accessed May 1, 2015).

${ }^{6}$ Carne Ross, and Nikolas Kozloff, “The Leaderless Revolution: How Ordinary People will take”, International Affairs (Royal Institute of International Affairs 1944-) 8(2), (March 2012): 400-407.

${ }^{7}$ Paul Samuelson, and William Nordhaus, eds. "Basic Elements of Supply ans Demand", in Economics, (New York: McGrae-Hill International, 2010): 45-64. 
mined by genetic and anatomical characteristics, gender is an acquired identity that is learned, changes over time, and varies widely within and across cultures. Gender is relational and refers not simply to women or men but to the relationship between them. ${ }^{8}$

Now this paper will be divided into two main parts. Part one will provide a criticism of how neoclassical economics is a theory of discrimination. It will argue for the non-existence of a separation between the global level and the social level when analyzing gender relations. The second part will discuss how structural adjustment programs affect women. Further it'll put and emphasis on women in poverty and armed conflict. The paper will end with a conclusion that provides my readers with an all-encompassing summery of my research findings.

\section{Review of Literature: Neo-Classical Economics-A Theory of Discrimination}

At the end of the Second World War, the ideologies of the United States and the Soviet Union were at odds. The two super powers could not reach an agreement on how to reconstruct the economies of the world-mainly Europe-that were destroyed by the war. The development strategies produced in the United States sought to contain communism while spreading capitalism throughout the world. The conflict that ensued came to be known as the Cold War and development strategy was only one of many arenas in which this clash played out. Years after the Cold War, prevailing development models still competed against the communist theory, which entails there should be a severe intervention and control of the market by the state, to prevent the emergence of a monopoly that exploits and alienates. ${ }^{9}$ One such model that competes with the communist model is the neo-classical economic growth model. Rooted in early economic thought, Neo-Classical development aims to spur economic growth through government support. A series of market failures in the 1960's led to the idea that the government should provide infrastructure to support the market, however any further intervention of the state in the market is not favored. Based on the theory of neo-classical economics, this model aims to construct organized markets to increase productivity and development through privatization, supply and demand, and mild intervention by the government. It hinges on the idea that investment will increase the growth rate of per capita output, making the commodities abundant and ultimately increase the income per capita. ${ }^{10}$

Neoclassical economics is defined by its reliance on rational choice theory and was largely established by homogeneous, typically white, male economists who

${ }^{8}$ Emily Esplen and Susie Jolly, "Gender and SEX", in Gender and Development, (United Kingdom: University of Sussex, BRIDGE, December 2006): 1-5.

${ }^{9}$ Lawrence King, and Patrick Hamm, "Privatization and State Capacity in Post-communist Society", Working Paper Series No. 806, (United States: William Davidson Institute, December 2005): 2-40

${ }^{10}$ Paul M. Romer, “Increasing Returns and Long-Run Growth.” Journal of Political Economy 94 (October 1986): 1002-37. 
were greatly influenced by Victorian ideology. ${ }^{11}$ This physical embodiment induced the reproduction of patriarchy over the years. ${ }^{12}$ This patriarchal, discriminatory root of neoclassical economics has led to the fallible analysis of women's role in the society. This perpetuated the notion that men are breadwinners and women are caregivers, which led the economists to view household labor as "women's work". However, this domestic role, which included social reproduction, was, and still is, considered to be unproductive and is categorized as leisure time. Leisure time includes time and production not exchanged for wages through the market. Women's productive but unpaid work, then, is labeled as leisure time, rendering this work invisible and unproductive, as it exists outside the sphere of the market. ${ }^{13}$

It is important to take into account the social exclusivity of neoclassical theory. One can make the argument that neoclassical economic theory possess the power of targeted-lending, i.e. the lending agent is reigned with the responsibility to determine who the beneficiaries within a particular nation are by setting forth criteria for eligibility (e.g. in order to "qualify" for microfinancing, the household's daily income ought to be less than \$xy). Based on such understanding, and as Atkinson (1998) contended, social exclusivity is intrinsically focused on the dynamics which have permitted the deprivation of some and inclusion of others to arise, be socially and institutionally reproduced, and structurally perpetuated. ${ }^{14}$ Furthermore, adopting social exclusion analysis lends itself to in-depth investigations regarding structural injustices within a particular society and situation, mindful of the intersectionality of characteristics, experiences, and realities (e.g. age, religion, physical ability, land-ownership, class, etc.), which could characterize and generate exclusion ${ }^{15}$ (Davis and Sanchez-Martinez, 2014:50). Additionally, mindfulness towards exclusion analysis allows for a shift in narrative where distributional issues and allocation of resources are problematic.

Stuart Mill ${ }^{16}$, took note of the exclusion and oppression of women. He argued for the devaluation of their productive contributions in 1869 and stated "All women (...) are brought up from the very earliest years in the belief that their ideal of character is very opposite to that of men; not self-will, and government by self-control, but submission, and yielding to the control of others...it is their ${ }^{11}$ The notion of separate spheres, which dictates that men, based primarily on their biological makeup as well as the will of God, inhabit the public sphere-the world of politics, economy, commerce, and law. Women's "proper sphere", according to the ideology, is the private realm of domestic life, child-rearing, housekeeping, and religious education. The separate spheres ideology presumes that women and men are inherently different and that distinctive gender roles are "natural".

${ }^{12}$ Chantel Young, eds. "Challenging Victorian Ideologies of Gender: The Problems of Contradiction", in The Story of an African Farm, (Australia: Edith Crown University, June 1991): 4-8.

${ }^{13}$ Marylin Waring, "If Women Counted: A New Feminist Economics", Off Our Backs 35(1/2), (January-February, 2005): 47-49.

${ }^{14}$ A Atkinson, "Social exclusion, poverty and unemployment", in ed A. Atkinson and J. Hills "Exclusion, employment and opportunity", LSE Case Paper 4.

${ }^{15}$ E Philip Davis and Miguel Sanchez-Martinez, "A Review of the Economic Theories of Poverty", National Institute of Economic and Social Research, (Discussion Paper No. 435), (2014): 42-52.

${ }^{16} \mathrm{~A}$ British philosopher, political theorist, and economist who lived from 1806-1873. 
nature to live for others". ${ }^{17}$ This bias view of women and the belief that it was their nature to live for others caused the influential neoclassical economists to label certain laborious activities as "women's work"; categorizing certain activities as natural duties rather than productive work worthy of material reward in exchange.

When addressing the effect of neoliberal policies, we must pay greater focus and directed our attention towards women and their specific experiences and issues regarding poverty. One of the major concerns for women is the accessibility of affordable services-an increasingly scarce resource. ${ }^{18}$ As part of the neoclassical agenda, increasing prices of commodities will lead to market equilibrium. However in lower-income working classes this is not the case, seeing that an increase in prices makes the commodity inaccessible for the poorer working classes in the developing countries. Women are more affected by the increase in prices than men, mainly because women are the financial managers of the household, making them the ones responsible for the purchasing of commodities. When an increase in prices occurs women usually seek jobs to help support their families. Therewith women carry the double-burden of housework and public employment. Consequentially this has come to be criticized and rejected by many, as policy makers are taking more from those who have less, for the sake of market equilibrium. One of the critiques is that the increase in prices widens the gap between the rich and the poor and perpetuates income inequalities, rather than decreasing the gap and satisfying the majority of the population. ${ }^{19}$

Furthermore, neoclassical economics treats labor as a commodity, which alienates and dehumanizes the labor. Commodifying the labor to neoclassical economics means the reduction of wages to increase profit. With that reduction of labor and the substitution of human labor with heavy machinery, decreased the opportunities for employment. The patriarchal nature of developing societies increases the probability of males' presence in public spheres and consequentially in the labor market. This increase in male presence in the labor market lowers the probabilities of female employment, resulting in the absence of women from the public sphere. This dilemma ultimately leads to the oppression of women and the violation of their rights to politically and socially participates. ${ }^{20}$ Additionally, with the treatment of labor as a commodity gender discrimination and gendered division of labor are further perpetuated, by further denoting women's role in productivity as one that is inferior to that of men. ${ }^{21}$

\footnotetext{
${ }^{17}$ John S. Mill, “The Subjection of Women”, (London: Longmans Green and Company, 1869): 8-45.

${ }^{18}$ Martha Macdonald, "Economic Restructuring and Gender In Canada: Feminist Policy Initiatives", World Development, 23(11), (1995): 2005-2017.

${ }^{19}$ Cesar Gallo, "Economic Growth and Income Inequality: Theoretical Background and Empirical Evidence", The American Economic Review XLV(1), (2002): 1-28.

${ }^{20}$ Samuel Bowls, and Herbert Ginits, "The Problem with Human Capital Theory-A Marxist Critique", The American Economic Review 65(2), (2003): 74-82.

${ }^{21}$ Hazel Reeves, and Sally Baden, "Gender and Development: Concepts and Definitions", BRIDGE no.55, (February, 2000): 1-37.
} 


\section{The Impact of Structural Adjustment Programs on Gender Dynamics}

Structural Adjustment Programs (SAPs) are a derivative from neoclassical economic theory, because at the time when the programs were initiated neoclassical economic theory was the dominant model and the one that seemed most successful. This helps in explaining the liberal approach apparent in the Structural Adjustment Programs. ${ }^{22}$

In the late 1970s and early 1980s, a difficult period had fallen upon the developing countries. This difficulty originated from high inflation causing the economy's growth rates to slow down dramatically, which led to the decline of earnings from exports, creating what we know as "trade deficit". These economic factors led to the intense deterioration of the national incomes of developing states, causing a depreciation of standards of living. In the 1980s however a glimpse of hope started to appear for the developing world when the Bretton Woods Institutions introduced stabilization and adjustment packages to them. ${ }^{23}$ The term "adjustment" connotes a variety of macro-economic mechanisms suggested by the Bretton Woods Institutions to rescue the economies of the developing countries. It frequently involved cutbacks in government expenditure. Consequently, government expenditure per capita fell in over half the countries of the developing world in the period 1980-1984. ${ }^{24}$ However this was not without a cost, the cuts in the government's public expenditure led to governments increasingly "laying off" workers, consequentially a melodramatic increase in the unemployment ratio in the developing world was to become visible. An analysis of several Latin American countries in the 1980s and 1990s illustrate that countries that had adopted the SAP had a relatively lower women's employment ratio than countries that did not. ${ }^{25}$ The study put an emphasis on the normalization of patriarchy in Latin American and lists it as one of the main causes for the unemployment of women in Latin America. The study also illustrates that when cutbacks in wages led to women seeking more than one job vacancy, yet there were none to be found because they were all reserved for men, who had physical superiority to women.

SAPs are often associated with Structural Adjustment lending. Globally, during 1999 and 2002 structural adjustment lending (SAL) constituted more than half of total Bank lending and in every year since 1998 it surpassed the Bank's own 25 percent ceiling on SAL spending. Gender activists believes that it is very important to ensure that SALs assist and do not harm the poor amongst whom

\footnotetext{
${ }^{22}$ Katarzyna Zawalinska, "What has been an economic impact of Structural Adjustment Programs on households in Transition countries?", in Development Studies: Institutions and Development, Cambridge: Cambridge University Press, (2003-2004): 1-15.

${ }^{23}$ World Health Organization, "Structural Adjustment Programs (SAPs)", Who.int, 2015, Web. http://www.who.int/trade/glossary/story084/en/, (accessed May 3, 2015).

${ }^{24}$ Francis Stewart, Richard Jolly, and Giovanni Cornia, eds. "Protecting the Vulnerable and Promoting Growth" in Adjustment with a Human Face, New York, Oxford University Press (1987): 463-480.

${ }^{25}$ Jennifer A. Ball, “The Effects of Neoliberal Structural Adjustment on Women's relative Employment in Latin America”, International Journal of Social Economics 31(10), (2004): 974-987.
} 
the majority are females. Since their 1979 inception SALs have had deleterious socioeconomic impacts especially on women who constitute $70 \%$ of the world's poor. Critics argue that SALs actually produce the opposite results. First, structural adjustment regulations constitute a reduction or elimination of public expenditures that had previously assisted the poor. This limits the poor's' income-generating opportunities through closing their jobs in order to fulfill the conditions imposed on global South governments. This in itself was problematic because it ended the "safety nets" that protected the most vulnerable, the poor and marginalized. ${ }^{26}$

Second, structural adjustment programs have proven to increase poverty in developing states, and to perpetuate class-relations, which consequentially perpetuate gender dynamics, causing women-70\% of the world's poor-to suffer more and to be more oppressed, and silenced. Johan Gultung made the argument that poverty is also a type of structural violence "I understand violence as the avoidable impairment of fundamental human needs or, to put it in more general terms, the impairment of human life, which lowers the actual degree to which someone is able to meet their needs below that which would otherwise be possible. The threat of violence is also violence". ${ }^{27}$

It has been argued by Easterly that "When the International Monetary Fund (IMF) and World Bank arrive in southern countries, corporate profits go up, but so does poverty and suffering. Decades of promises that just a little more 'short-term' pain will bring long-term gain have exposed the IMF and World Bank as false prophets whose mission is to protect those who already control too much wealth and power". ${ }^{28}$ In the Economic Commission for Africa discussion in 2008, when SAPs are applied in countries who already have more than $12 \%$ of the population living under the UN defined poverty line-i.e. living under $2 \$$ a day-the program is $42 \%$ more likely to fail. In the report it was mentioned that under the policies of SAP families tend to decrease their expenditure as well by pulling women out of school, and having them work instead. A country in Africa that is undergoing structural adjustment has the effect of $78 \%$ chance of female children being pulled out of school and a $32 \%$ chance of male children to be pulled out of school. Therewith females with only primary education have fewer chances of finding employment than their counter-partners especially in their young/adult lives (Figure 1).

The discussion that was held by Professor Aigbokhan, was concluded on the remark that the more illiterate females are, the more their chances for a better lifestyle decreases, and the slower the process of development in that country is. ${ }^{29}$ This further highlights the unequal opportunities between male and female, ${ }^{26}$ Doris A. Oberdabernig, "The Effects of Structural Adjustment Programs on Poverty and Income Distribution", The WIIW Report (March, 2010): 2-36.

${ }^{27}$ Johan Gultung, "Kulturelle Gewalt”, in Der Bürger im Staat 43(2), (1993): 106.

${ }^{28}$ William Easterly, “The effect of IMF and World Bank Programs on Poverty", Imf.org, October 31, 2000, Web. https://www.imf.org/external/pubs/ft/staffp/2000/00-00/e.pdf, (accessed May 3, 2015).

${ }^{29}$ Ben E. Aigbokhan, "Incidents and Dimensions of Poverty in Nigeria", in Growth, Inequality, and Poverty in Nigeria, Ethiopia: United Nations Economic Commission for Africa (February, 2008): 11-25. 


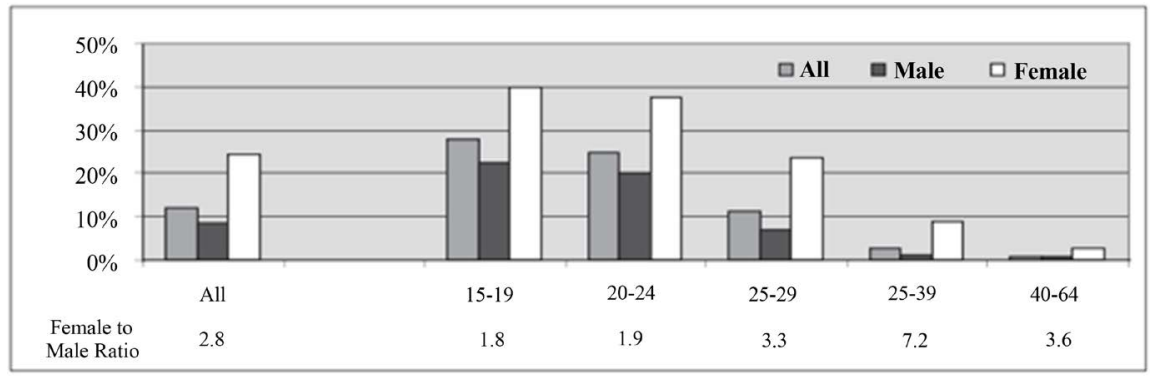

Soure: 2002 Labor Force Survey

Figure 1. Unemployment rates by age (2002).

which are further inflamed by structural adjustment and patriarchy. Poverty rates and its effects on gender equality, brings me to my third point. How poverty, gender and civil wars are correlated.

\section{Chronic Poverty-Why SAP have failed}

The correlation between poverty and civil war has indeed been proven. Project Ploughshares' Armed Conflict Report 2011 has shown 26 armed conflict reports around the world in 20 different countries. ${ }^{30}$ Analyzing the causes for those armed conflicts, a research has shown that most of the counties who suffered from extreme poverty and had received loans from the IMF and the World Bank on numerous occasions. ${ }^{31}$ Furthermore a research dedicated to the case of the Sub-Saharan Africa stated "IMF conditionality, however, has led to a host of problems in sub-Saharan Africa that potentially increase the risk of experiencing internal conflict. The results of this research demonstrate that the implementation of the Enhanced Structural Adjustment Facility significantly increases a country's risk of experiencing armed civil conflict (...) by required policies that had particularly negative consequences for the poor, such as currency devaluation and social spending cuts. Decreased patronage resources limited governments' ability to provide concessions or side-payments to potentially restive populations. Finally, cuts in military spending may have made states unable to quash rebellion when it did occur". ${ }^{32}$

Another study carried out by Harvard University declares that poor-income countries are more inclined to have civil wars than middle- or high-income countries, and that is due to several reasons as mentioned in the study. 1) Poor countries tend to have large youth bulges, 2) the educational level in poor countries tend to be noticeably low, 3) poor countries depend heavily on their natural endowments, and finally 4) poor countries have poor governance and a weak economic performance. Those factors relate to one another in the following manner: when poverty is high, families of the rural areas (who are the majority), ${ }^{30}$ Ploughshares Armed Conflict Report, "2012 Armed Conflicts Report Summary", The Ploughshares Monitor 33(2), (2012).

${ }^{31}$ Yanyu Ke, "Structural Adjustment Programs and Armed Civil Conflict: Introduction and Existing Theoretical Approaches", in The Medicine of War: IMF Structural Adjustment, Ethnic Politics, and Armed CivilConflict, United States: University of Kentuky, (2014): 8-26.

${ }^{32}$ Claire D. Gowen, "Armed Civil Conflict, Forms of Conditionality, and Economic Grievances", in IMF Conditionality and Armed Civil Conflict: An Analysis of Sub-Saharan Africa, Thesis, Georigia State University, (2007): 25-31. 
tend have high fertility rates in order for the young to work on the field. ${ }^{33}$ Seeing that a lot of developing countries are still restrained by their natural endowments and have not yet developed to a Newtonian society, it is of no shock to know that children usually receive no education that would burden the family with its expenses.

The nonexistence of proper healthcare systems and the environmental pollution in poor-income countries also contribute to the high rates of death in elder population, leaving the majority (around 60\%) of the society between the ages of $14-25 .{ }^{34}$ Scholars have argued that poverty increases opportunities for rebellion since large numbers of youth provide a ready potential supply of rebel combatants. For example, a recent Population Action International report finds that, "on average, the decline in the annual birth rate of five births per thousand people corresponded to a decline of about 5 percent in the likelihood of civil conflict during the following decade-descending from more than 40 percent likelihood in the earliest phase of demographic transition to less than 5 percent in the latest" ${ }^{35}$ The theory could be better illustrated through using the example of Syria. In 2002 the youth/adult unemployed population was 65\% (Figure $2 \&$ Figure 3).

Using these findings one can logically correlate the emergence of a youth revolution in Syria that rebelled the existing government. Noah Q. Bricker and Mark C. Foley make the argument in their paper that the youth bulge was indeed the reason behind the 2011 uprising in Syria. They continue to explain how the violent response of the Bashar regime to the graduate unemployment crisis has led to the eruption of civil war in Syria. ${ }^{36}$

Robert Springborg analyzed the reasons for the Arab uprisings in 2011 and concluded by stating that there are seven demographic deficits that have contributed to the uprisings: the populations in the Arab world are 1) too young, 2) too rural, 3) too poorly educated, 4) too lacking of skills and training, 5) too dependent on the government to provide for their lives, 6) too poor, and lastly 7) too lacking of a middle class. ${ }^{37}$ His analysis was followed by the logic that the income per capita in Arab states, especially in republics like Syria, Egypt, Tunisia, and Libya, have contributed to the dissatisfaction of the population. Furthermore, he emphasized that the republics who have faced the most severe types of uprisings have all received international loans, and have at some point been forced into structural adjustment programs.

It is thus widely believed that SAPs increase the probabilities of civil wars, by ${ }^{33}$ Jeffrey Sachs and the U.N. Millennium Project, "Investing in Development: A Practical Plan to Achieve the Millennium Development Goals”, United Nations Development Program, 2005.

${ }^{34}$ U.N. Population Fund, "Population and Poverty: Achieving Equity, Equality and Sustainability", Population and Development Strategies Series, No. 8, (2003): 25.

${ }^{35}$ Richard Cincotta, Robert Engelman, and Daniele Anastasion, “The Security Demographic: Population and Civil Conflict After the Cold War", Population Action International, (2003): 12.

${ }^{36}$ Noah Q. Bricker, and Mark C. Foley, “The Effect of Youth Demographics on Violence: The Importance of the Labor Market”, International Journal of Conflict and Violence 8(1), (2013): 1-15

${ }^{37}$ Robert Springborg, “The Precarious Economics of the Arab Spring”, Survival: Global Politics and Strategy, issue no. 53:6, 2011, p.85-104. 


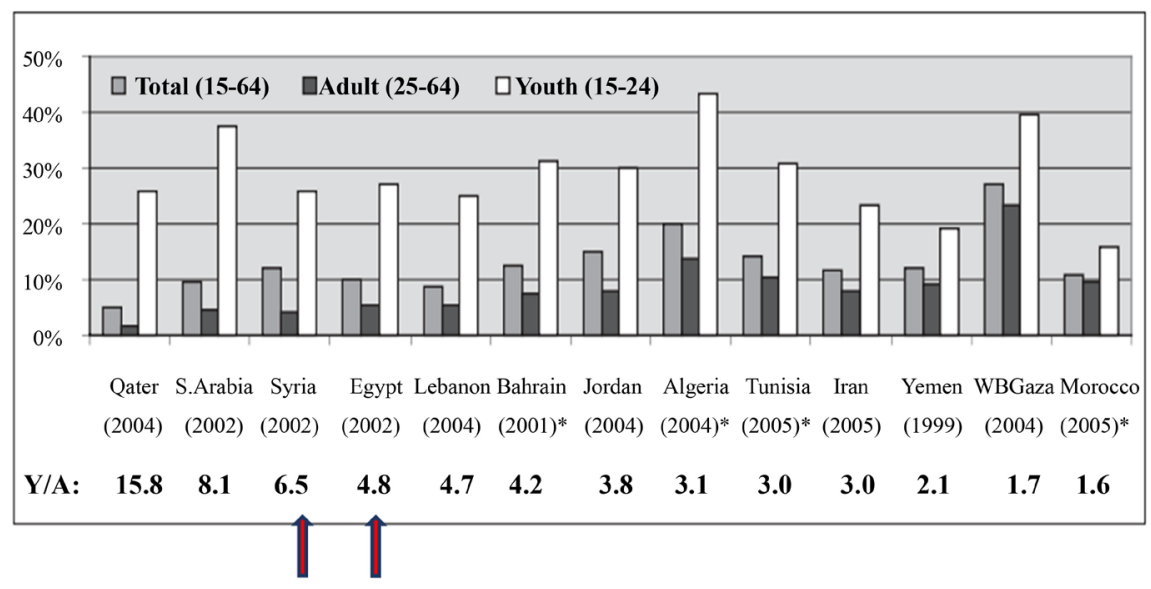

Sources: Kabbani \& Kothari (2005), ILO (2006a), UNDP Lebanon (2007). *Estimates include age 65+. Unemployment estimates for Qatar, Saudi Arabia and Bahrain are for national workers.

Figure 2. Youth/Adult unemployment rates and ratios, middle eastern countries.

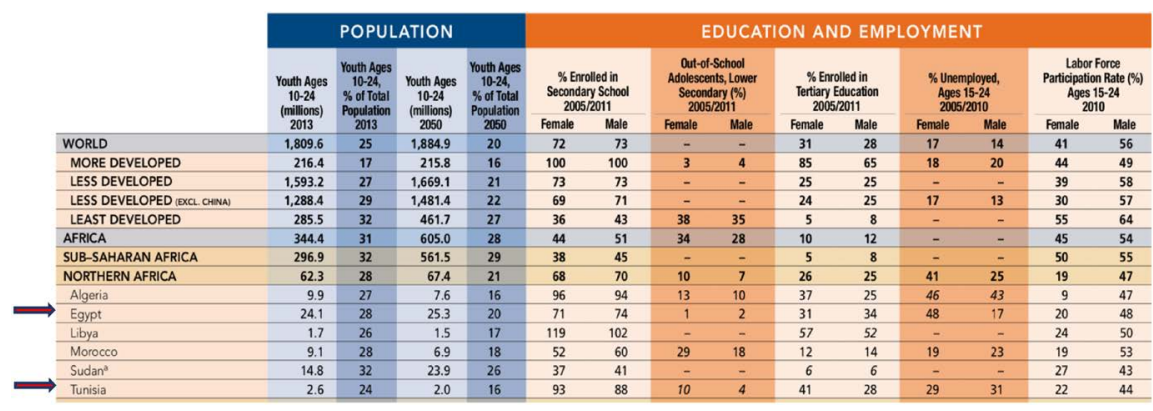

Figure 3. Population Reference Bureau (2013). Source: Population Reference Bureau 2013 (http://www.prb.org/pdf13/youth-data-sheet-2013.pdf).

forcing liberalization, which is like "spreading the seeds of war" because economic liberalization, which generates "losers"-i.e. those who were fired from their jobs and still want to provide for their families, so they become part of the informal sector, join the informal sectors of the economy such as coping-, combat-, and criminal informal economy-who due to their dissatisfaction with the current economic status of the country and foment civil unrest leading to a civil war. ${ }^{38} \mathrm{IMF}$ actually liberalizes countries and that liberalization is what causes the conditions of conflict, rather than solving the crisis. ${ }^{39}$ Unfortunately, the IMF and similar institutions do not calculate the effects of the imposed liberalization, which leads to their projects being poorly grounded in theories-liberalism and neo-liberalism, which are associated with neoclassical economic theory, from which modernization theory is derived-that are insufficient and problematic. The effect of war on women is that it makes the women's womb the battlefield. Women's bodies are made insecure during wartime, due to the lack of supervision by governments and the absence of the rule of law, make violations of the ${ }^{38} \mathrm{~V}$. Spike Peterson, eds. "Gendering Informal Economies in Iraq" in Women and War in the Middle East, London: Zed Books, (2009): 35-64.

${ }^{39}$ Trude M. Midtgaard, Krishna Chaitanya Vadlamannati, and Indra de Soysa, eds."Does the IMF cause Civil War? A Comment", The Review of International Organizations 8(1), (2013): 5-30. 
woman's body a social reality that has to be endured because there are matters of higher significance, like nutrition and material security. Rape is one of the mechanisms employed in wartime, especially during civil wars. It is used as a weapon of war and allows lawlessness to prevail; therewith women become targets from all sides in a conflict, regardless of which side they are on. Sexual violence is systematically employed to harm and demoralize individuals, break apart families and terrorize the opposition. ${ }^{40}$

These factors combined prove that structural adjustment does more harm than good. It increases the probability of armed conflicts, it dehumanizes women making them seem as the underclass of the working class, and it increases poverty and illiteracy. ${ }^{41}$

\section{Conclusion}

Throughout this paper it has been demonstrated that neoclassical economic theory is one that perpetuates gender relations through forcing women into the private sphere and silencing their voices who call for liberty from the dominant. The paper was divided into two parts, part one discussed how neoclassical economic policies have effected gender relations on a global level. The first part reiterates the idea that there is no distinction between the world order and the social order, and that states are the intermediate between both, yet they are not in isolation from one another. This explained how power relations exercised and showcased on the global level affect gender relations on the social level.

Part two of the paper emphasized Structural Adjustment Programs and Structural Adjustment Lending, which I have proven to be one of the many variables responsible for the perpetuation of patriarchy. Structural adjustment has been illustrated for what it truly is, a system maintainer. It propagates advancement and delivers poverty, illiteracy, civil wars and unemployment.

Therewith I conclude that neoliberalism is, in parallel existence with neo-liberal policies, the global world order, and the unequal distribution of power relations, is one of the causes for the underdevelopment of the developing states, the perpetuation of patriarchy, and the dehumanization of women. I offer scholars of the hegemonic powers to look at alternative theoretical perspectives for their analysis and the planning of projects to use a more critical theoretical framework, such as Feminist Marxism, Historical Materialism, Post-structuralism, and Post-colonialism. My reasoning is that those theoretical frameworks are not blind to gender relations or class relations. Furthermore, they use a bottom-up approach when analyzing power relations, regardless of whether they are intra-state or inter-state.

\section{Conflicts of Interest}

The author declares no conflicts of interest regarding the publication of this paper.

${ }^{40}$ International Rescue Committee, “The Forgotten Frontline: The Effects of War on Women”, Rescue.org, 2014, Web. http://www.rescue.org/forgotten-frontline-effects-war-women, (accessed May 3, 2015).

${ }^{41}$ Mayra Buvinic, "Women in Poverty: A New Global Underclass", Foreign Policy, (Fall, 1997): 1-13. 


\section{References}

Ball, J. A. (2004). The Effects of Neoliberal Structural Adjustment on Women's Relative Employment in Latin America. International Journal of Social Economics, 31, 974-987. https://doi.org/10.1108/03068290410555426

Bowls, S., \& Ginits, H. (2003). The Problem with Human Capital Theory-A Marxist Critique. The American Economic Review, 65, 74-82.

Bradshaw, S., Castellino, J., \& Diop, B. (2012). Women's Role in Economic Development: Overcoming the Constraints. In Challenges of Social Inclusion: Gender, Inequalities and Human Rights (pp. 1-15). New York: Middlesex University Press.

Bretton Woods Projects (2005). What Are the Bretton Woods Institutions. BrettonWoodsProject.org. http://www.brettonwoodsproject.org/2005/08/art-320747/

Bricker, N. Q., \& Foley, M. C. (2013). The Effect of Youth Demographics on Violence: The Importance of the Labor Market. International Journal of Conflict and Violence, 8 , $1-15$.

Buvinic, M. (1997). Women in Poverty: A New Global Underclass. Foreign Policy, No. 108, 1-13. https://doi.org/10.2307/1149088

Cincotta, R., Engelman, R., \& Anastasion, D. (2003). The Security Demographic: Population and Civil Conflict after the Cold War. Population Action International, 12.

Easterly, W. (2000) The Effect of IMF and World Bank Programs on Poverty. https://www.imf.org/external/pubs/ft/staffp/2000/00-00/e.pdf https://doi.org/10.2139/ssrn.256883

Esplen, E., \& Yolly, S. (2006). Gender and SEX. In Gender and Development (pp. 1-13). Sussex, United Kingdom: University of Sussex, BRIDGE.

Gallo, C. (2002). Economic Growth and Income Inequality: Theoretical Background and Empirical Evidence. The American Economic Review, 45, 1-28.

Gowen, C. D. (2007). Armed Civil Conflict, Forms of Conditionality, and Economic Grievances. In IMF Conditionality and Armed Civil Conflict: An Analysis of Sub-Saharan Africa (pp. 25-31). Atlanta, GA: Georgia State University.

Gultung, J. (1993). Kulturelle Gewalt. Der Bürger im Staat, 43, 106.

International Rescue Committee (2014). The Forgotten Frontline: The Effects of War on Women. http://www.rescue.org/forgotten-frontline-effects-war-women

Ke, Y. Y. (2014). Structural Adjustment Programs and Armed Civil Conflict: Introduction and Existing Theoretical Approaches. In The Medicine of War: IMF Structural Adjustment, Ethnic Politics, and Armed Civil Conflict (pp. 8-26). Lexington, KY: University of Kentucky.

King, L., \& Hamm, P. (2005). Privatization and State Capacity in Postcommunist Society (pp. 2-40). Working Paper Series No. 806. Ann Arbor, MI: William Davidson Institute. https://doi.org/10.2139/ssrn.905879

MacDonald, M. (1995). Economic Restructuring and Gender in Canada: Feminist Policy Initiatives. World Development, 23, 2005-2017. https://doi.org/10.1016/0305-750X(95)00080-V

Mill, J. S. (1869). The Subjection of Women (pp. 8-45). London: Longmans Green and Company.

Oberdabernig, D. A. (2010). The Effects of Structural Adjustment Programs on Poverty and Income Distribution (pp. 2-36). The WIIW Report.

Ploughshares Armed Conflict Report (2012). 2012 Armed Conflicts Report Summary. The Ploughshares Monitor, 33. 
https://ploughshares.ca/pl_publications/2012-armed-conflicts-report-summary/9/

Reeves, H., \& Baden, S. (2000). Gender and Development: Concepts and Definitions. BRIDGE, No. 55, 1-37.

Romer, P. M. (1986). Increasing Returns and Long-Run Growth. Journal of Political Economy, 94, 1002-1037. https://doi.org/10.1086/261420

Ross, C., \& Kozloff, N. (2012). The Leaderless Revolution: How Ordinary People Will Take. International Affairs, 8, 400-407.

Sachs, J., \& the U.N. Millennium Project (2005). Investing in Development: A Practical Plan to Achieve the Millennium Development Goals. United Nations Development Program. https://doi.org/10.1016/S0140-6736(05)70201-4

Samuelson, P., \& Nordhaus, W. (2010). Basic Elements of Supply and Demand. In Economics (pp. 45-64). New York: McGraw -Hill International.

Sirolli, E. (2012). Want to Help Someone? Shut up and Listen. Ted.com/Talks. https://www.ted.com/talks/ernesto_sirolli_want_to_help_someone_shut_up_and_liste n/transcript?language $=$ en

Spike, P. (2009). Gendering Informal Economies in Iraq. In Women and War in the Middle East (pp. 35-64). London: Zed Books.

Springborg, R. (2011). The Precarious Economics of the Arab Spring. Survival: Global Politics and Strategy, 53, 85-104. https://doi.org/10.1080/00396338.2011.636271

Stewart, F., Jolly, R., \& Giovanni, C. (1987). Protecting the Vulnerable and Promoting Growth. In Adjustment with a Human Face (pp. 463-480). New York: Oxford University Press.

The Business Dictionary (2015). Definition: Neo Classical Economics. Businessdictionary.com, 2015, Web.

http://www.businessdictionary.com/definition/neo-classical-economics.html

U.N. Population Fund (2003). Population and Poverty: Achieving Equity, Equality and Sustainability. Population and Development Strategies Series, No. 8, 25.

Waring, M. (2005). If Women Counted: A New Feminist Economics. Off Our Backs, 35, 47-49.

World Health Organization (2015). Structural Adjustment Programs (SAPs). https://apps.who.int/iris/handle/10665/193994

Young, C. (1991). Challenging Victorian Ideologies of Gender: The Problems of Contradiction. In The Story of an African Farm (pp. 4-8). Australia: Edith Crown University.

Zawalinska, K. (2003-2004). What Has Been an Economic Impact of Structural Adjustment Programs on Households in Transition Countries? In Development Studies: Institutions and Development (pp. 1-15). Cambridge: Cambridge University Press. 